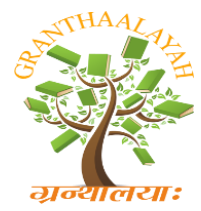

INTERNATIONAL JOURNAL OF RESEARCH GRANTHAALAYAH

A knowledge Repository



Social

\title{
CONSTRUCTIVIST APPROACH: CREATING A MEANING TO LEARNING
}

\author{
Dr. Prabha S. Chiniwar $*^{1}$ \\ ${ }^{* 1}$ Principal, Prerana Public School, Vijaypur - 586101, St: Karnataka, INDIA
}

DOI: https://doi.org/10.29121/granthaalayah.v4.i9(SE).2016.2506

\begin{abstract}
The author is wholly concerned with the unstressed learning of the students for which he wants to revolutionize the way of teaching English. A foreign language is learnt specially with the translation method is the practical side of the language learning. The author has experienced the various learning criteria of learning language as he has been working in the Tribal Institution. For the infants the most practical and fruitful method we have gone through is the Direct Method of language learning. The Direct Method refers to the 'Direct approach in the language application'

The words, 'This', 'That', envisage to the appetite of understanding the information of the object. These words are to be regarded as the model words of the 'Direct Method.'

In language learning, the presentation of the objects or the things put a sort of stress on the views of the students that is accompanied with the experience. The author is feasibly concerned with the - 1. Actual understanding of the language by the student, 2. Throughout application of the language by the student, 3. The proper information and stress on the words by the students and 4. Beneficence of the learnt language to the student. We look in for the various methodologies in making language learning easy.
\end{abstract}

Keywords:

Constructivist Approach, Methodology, learning, teaching etc.

Cite This Article: Dr. Prabha S. Chiniwar, "CONSTRUCTIVIST APPROACH: CREATING A MEANING TO LEARNING”, International Journal of Research - Granthaalayah, Vol. 4, No. 9: SE (2016): 18-25.

\section{INTRODUCTION}

No Real Learning Can Take Place without Enjoyment

The National Education Policy was declared in 1986. According to this policy in 1988 many states including Karnataka revised and regulated an improved curriculum for the primary, middle 
and higher middle stage. The National Education Policy expected teaching of Languages other than Mother tongue from Standard VI but Karnataka retained the teaching English from Std. V.

Today English has received the place of international language. Japan, China and Russia like socialist country progressed in the field of Science, Technology and Industry even being educated through their national languages knowing the importance of English as an international language preferred English in the recent decades.

This age is fore coming as the age of computer. English being the language of computer it has become necessary for all to learn English. Altogether the language of knowledge, Science, Technology, international trade and information technology it is the need of time to learn the global language. So, all the states have devised a new policy regarding English.

\section{GENERAL AIMS OF TEACHING ENGLISH AND TEACHER'S EFFORTS}

The study of a language has four aspects as follows.

1) The Semantic aspect

2) The phonetic aspect

3) The Graphic aspect

4) The Phonetic-cum-Graphic aspect.

$>$ The semantic aspect deals with the understanding of the meaning

$>$ The phonetic aspect deals with spelling and pronunciation of words

$>$ The graphic aspect deals with the written form of a language

$>$ The phonetic-cum-graphic aspect deals with reading of language.

All these aspects are co-related to each other. No one of them can be isolated from each other. Considering the above aspects of English language learning the following four aims are formulated.

1) To enable the pupils to hear and understand spoken English

2) To help them acquire proficiency in speaking English

3) To enable them to understand what they read in English

4) To enable them to write in English.

From the above aims it can be concluded that the task of an English teacher is to train the hearing, reading, speaking and writing abilities of his pupils. In the same way the practical side of these aims proposes that the students should be able to speak and write on their own accord.

Overcoming the above stated aims many English experts and researchers have suggested a number of methods. The author is curious of finding new ways or the processes of teaching English in easy way.

In case of learning a foreign language like English the habit formation must be concentrated upon by the teacher. English as a foreign language would present psychological difficulties which the teacher should face intelligently. For instance a child many not feel interested in learning an additional language. He may find peculiarities of pronunciation of words and their 
uses. Peculiarities in the formation of structure and may find something new and strange about English. In this situation the teacher has to attract attention of his pupils to his own personality, befriend them and win their full confidence.

As stated above the experts have given many ways of teaching language. The teaching of English is supported with many methods e.g. Recitation of words, translations method, habit formation, structural approach, and grammar method etc. among the above only translation method is proved to be useful to a large extent, but it created the problem of formation of structure or sequence of words.

The Govt. of Maharashtra has introduced English from std I. since June 2000. The curriculum authority supported the DIRECT METHOD of teaching English. Basically the Govt. provided the books those are highly stressing the use of Direct Method.

Although the committee stated, "The book is child centered, activity oriented, pictorial and colorful. We have been eclectic in choice of methods and techniques so that any primary teacher would find it convenient to handle English as a subject"

Freedom unto some extent is given to the teacher through the word ECLECTIC meaning choosing from various sources. But going through the books from standard I to VII it is clear that the committee expected a large application of Direct Method.

The author in his constructive efforts coordinated the relation of various teaching aids or projects and easy learning of language. Going details the mechanism of constructive efforts, let us discuss some of the barriers in easy learning of English.

\section{MAJOR BARRIERS IN THE EASY LEARNING OF ENGLISH}

1) An uninvited fear of a foreign language.

2) Total disparity with the mother tongue.

3) Disparity of the structure of English and mother tongue.

4) Insistence of grammatical correctness while speaking/talking.

5) Less duration for the application, chance and linguistic atmosphere.

6) Scarcity of skilled English teachers.

7) Scarcity of supper trainers and trainees as well.

8) Negativity of the teachers in using authentic or an applied method.

9) Qualification of the teacher.

\section{CONSTRUCTIVE MECHANISM OF THE INNOVATOR}

When we ponder upon the syllabus of the primary classes for English meticulously we have a chance to conclude that it is basically cemented on the principle of materialism. Considering the principle the students need to see 'Something' and the teacher should have 'something' to be shown to the students. The author experienced the following advantages of the material things over the usual way of teaching and learning.

1) Model things put no stress on the imagination power of the learner. 
2) Model things produce thinking and feeling process in the mind of the learner.

3) It saves the energy of the teacher that he would have needed for extra explanation. Model things are self-expressive.

4) Model things bring out more responses. A mute child is supplied itself with the concealed energy within itself. Frequency of responses is increased.

5) Model things help in attracting the attention of the mass. It creates competitive atmosphere in the classroom.

6) Model things support the play way method suggested by the committee.

7) Model things help the less able teacher to overcome his task of teaching.

8) The learner remains no passive listener or observer, but an active responder physically or mentally.

9) Model things support 'Language In Action'

10) Model things touch many theories of teaching and learning.

\section{INNOVATIVE AIDS USED FOR EASY LEARNING OF ENGLISH}

\subsection{WORD CARD PROJECT}

\section{Plan of the Project}

This project consists of a card of an identity card size pinned to the shirt on the chest place. The card imprinted with two English words of the font size of 28pt. that could be clearly seen from the distance of 30 feet. The project was practiced on the students of std. IV to X

\section{Project Running Process}

1) Every student was given a card bearing two words. He was made compulsory to find the meaning from the dictionary or by asking to anybody who knows.

2) Some of the students were called on the stage while the Morning Prayer to tell the meaning of the word.

3) The cards were exchanged every day among the students. The rotation may repeat the word.

\section{Objectives of the Project}

1) To enhance the words vocabulary

2) To enhance the spelling memory

3) To create the atmosphere of learning English.

\section{Output of the Project}

1) Students were observed taking interest in the spellings of the words.

2) Students were observed discussing the use of the words in sentences.

3) Students called each other by the 'word' itself.

4) Vocabulary of the students was found increased to a good extent within two months.

5) Students were observed referring dictionary, contacting teachers and elders for the meanings of the words.

6) Students answer the meanings of the words to a large extent.

7) Students were observed mixing the words with their mother tongue. 


\subsection{HANGING LIBRARY}

\section{Plan of the Project}

This project is not invented by us. Running this project in our school continuously for six years under the Neem tree in open air has become the specialty of our school in the district.

The project is set up under a Neem tree that has the feature of a large umbrella. Eight wooden pillars are woven with metal wires to hang the chronicles, monthly magazines, newspapers and small booklets in English language.

\section{The Project Running Process}

The students prefer the books other than the text books. Keeping intact the psychology of the students, verity of the books were collected and hanged on the wires. Students crowded to read the chronicles, newspapers and booklets while the intermission of the school, before and after the time of the school.

\section{Objectives of the Project}

1) To create the English learning atmosphere in the school.

2) To enhance the English vision of the students.

\section{Output of the Project}

1) Students were observed discussing the spellings, length of the words, font of the words etc.

2) Words identification was found enhanced.

\subsection{COMMUNITY LEARNING ENGLISH PROJECT}

\section{Plan of the Project}

"Reading makes a full man, writing an exact man and a conference a ready man."

\section{-Francis Becon}

CONFERENCE is the basic theme of the project. The project consists of a large clothe screen, overhead projector, photo films slides, wireless microphone, pointer, sound system and an expert English teacher.

\section{The Project Running Process}

As is the name of the project it conducted in the community hall, where all the students of the school were gathered. Here, large pictures of items were focused on a large screen. The teacher managed communication in English with the students with the help of the picture on the screen. Students did not bring any learning material like pen, pencil, text book, note book or slate. They will come free - hand in either dress, and walked away joyfully. The project was conducted at 6 to 7 evening.

\section{Principle behind the Project}

1) Large pictures attract the students at a large scale.

2) Throughout the day a novelty in learning is created. 
3) Gathering of the students in a large classroom create competitive atmosphere, boldness, joy of learning and concentration.

4) Inner will of learning and teaching of the student and the teacher is increased.

5) English learning atmosphere is created.

\section{Objectives of the Project}

1) To enhance the listening skill of the students.

2) To diminish an uninvited fear of the foreign language, English.

3) To implement the practical application of the English language.

4) To save the energy that requires in class wise teaching including a large number of students.

5) To impart the training of conference skill on a large scale

6) To create the total English learning atmosphere.

7) To gather the concentration for learning English.

8) To develop the confidence for communication in English language.

\section{The Output of the Project}

1) The uninvited fear of English language was observed expelling away from the mind of the students.

2) Students were observed practicing simple sentences while talking.

3) Time of the English teacher was saved to fifty percent.

4) Students were observed responding to the questions asked in English.

5) The evening time, 6 to 7 was observed creating English learning atmosphere.

6) The concentration of the students was gathered at a large scale

\subsection{SHOPPING SYSTEM}

\section{Principle behind the project}

In the Direct Method of teaching it is essential that the students be shown some objects to create the effective communication. The author feels that a verb and noun are the important words in a sentence for communication. Unless the student know the name of the object it is quite difficult for him to start to speak about the object.

\section{Process of running the project}

Market of various shops were created like cosmetics, medicine, hardware, bakery, general store, book stall grocery; shoe shop etc, the shops consists of the empty packets of the things.

In the activity part of the text book, students were introduced to these amusement shops. The teacher was the shopkeeper. In this project the teacher performed thorough communication in English by asking various questions or by answering various questions of the students even s/he uses mother tongue.

\section{Objectives of the Project}

1) To enhance the noun vocabulary

2) To connect English language with their daily routine and transactions. 


\section{Output of the project}

1) The students knew the names of the various things in the shops.

2) The students were attracted towards the application of the language.

\subsection{WALL WORDS BELT}

\section{Theme of the project}

Ours is a day school. The students remain in the premise of the school for 8 to 9 hours. For the projection of the eye sight of the students a Words Belt project is run.

The aid consists of a words belt on the wall at the height of two feet from the floor in varandha. The word size measuring $12 \times 10 \mathrm{cms}$. The size of the words is maintained that could be seen from the distance of even hundred feet.

\section{Objectives of the Project}

1) To create the mentality of reading English imperceptibly.

2) To create the English Language atmosphere.

\section{Output of the Project}

1) The students are observed playing end letter game (Antakshari), pre letter game concerning the spellings of the words.

2) Students are observed tracing the fingers on the words mumbling the spellings.

3) Unskilled teachers are observed giving the class work while engagement

\subsection{REPEATED LISTENING THROUGH TAPE RECOREDER}

\section{Theme of the Project}

Saving energy of the teacher that requires for repeated reading was the basic theme of the project. The project consists of a tape recorder that would run on DC power of 6 volt, blank cassettes and a skilled teacher.

\section{Process of Running the Project}

The author had recorded the material from the text books class wise and would play the recorder whenever he wanted to do so. The software consists of an excellently pronounced sentences, story, lessons and poems.

\section{Objectives of the Project}

1) To support the ear training of the students.

2) To save the energy of the teacher.

3) To hear the well pronounced texts.

\section{Output of the Project}

1) The project helped the students to know the pronunciation of the words whenever he required.

2) The project helped the students to know the reading style, stress and intonation whenever he required.

3) The project saved the energy of the teacher.

4) Unskilled teacher could manage the reading. 


\subsection{WALL PAINTINGS}

\section{Theme of the Project}

The students are normally attracted towards the bigger coloured pictures rather than the pictures in text book.

This mentality of the students was used for learning English easily. The painting consists of active pictures.

\section{Objectives of the Project}

1) To try to fulfill the appetite of learning English without text book

2) To apply the model words 'this' and 'that' on the primitive stage.

\section{Output of the Project}

1) The project helped the teacher to prepare more questions on continuous tense.

2) The students observed discussing the activities in the pictures in continuous tense.

\section{CONCLUSIONS}

The Various language teaching/learning projects lured the students to learn the English language to a great extent. A revolutionary atmosphere of learning English was created through the various projects. Many teachers got the instigation to teach English in easy way. Tension of learning a foreign language was found released to a great extent. Students used simple sentences to communicate. Responding to an English question was found increasing. The projects helped the students to translate English matter in their mother tongue.

\section{REFERENCES}

[1] Agrawal, A. C. Educational Research, Ashish Publishing House, Arya Book Depot, 1991.

[2] Bhintade V. R. (Dr.), Educational Research Methods, Nutan Publications Pune, 1989

[3] Buch M. B., (1978-1983), Third Survey of Education, Baroda University.

[4] Buch M. B., (1983-1988), Fourth Survey of Education, Volume I,NCERT.

[5] Chaudhari Prabhakar(Dr.) (1999): Teaching of English, Vankatesh prakashan Jalgaon.

[6] Geetha Nagraj, English language Teaching, Approaches, Methods, Techniques, Orient Longman Limited, Calcutta, 2000.

[7] Golden, S. A. R. (2011). Problems and Prospectus of Distance Learning. Bharathidhasan University, 343, 344.

[8] Golden, S. A. R. (2011). Strategy For Success Of Human Beings:-Time Management.

[9] Mahurkar Sangita (Dr.),(September 2000), Pg. No. 6., CTE-01 The Language Learner :The Nature of Language 2., New Delhi, IGNOU CTE Course Book.

[10] Nanda J. K. Pg. No. 9-11., Improve Your Spoken English, New Delhi, Hallmark (India) Publishers.

[11] Oxford Illustrated Dictionary, Oxford University Press, New Delhi.

[12] Shikshan Sankraman, Feb-2006, Progressing towards English Communication through confidence, M. S. S. \& H. S. Board, Pune. 